\title{
MODERN CHALLENGES OF GLOBALIZATION PROCESSES AND INTERCULTURAL COMMUNICATION AS AN ANSWER TO THEM
}

\author{
Maya Trynyak ${ }^{1}$, Viktoriia Tykhonovych ${ }^{2}$, Nataliia Skinder ${ }^{3}$, Iryna Torianik ${ }^{4}$, \\ Nataliia Rezenkina ${ }^{5}$, Tetiana Teterina ${ }^{6}$ \\ ${ }^{1}$ Department of philosophy, H. S. Skovoroda Kharkiv National Pedagogical University, Kharkiv, Ukraine \\ maya1973trynyak@gmail.com \\ ORCID: http://orcid.org/0000-0003-4981-8535 \\ ${ }^{2}$ Department of Tourism and socio-humanitarian disciplines, Kharkiv College of Trade and Economics of Kyiv National University of \\ Trade and Economics, Kharkiv, Ukraine \\ ORCID: http://orcid.org/0000-0002-0232-3001 \\ ${ }^{3}$ Department of Tourism and socio-humanitarian disciplines, Kharkiv College of Trade and Economics of Kyiv National University of \\ Trade and Economics, Kharkiv, Ukraine \\ ORCID: http://orcid.org/0000-0003-4027-6418 \\ ${ }^{4}$ Department of Tourism and socio-humanitarian disciplines, Kharkiv College of Trade and Economics of Kyiv National University of \\ Trade and Economics, Kharkiv, Ukraine \\ ORCID: http://orcid.org/0000-0002-2169-748X \\ ${ }^{5}$ Department of Tourism and socio-humanitarian disciplines, Kharkiv College of Trade and Economics of Kyiv National University of \\ Trade and Economics, Kharkiv, Ukraine \\ ORCID: http://orcid.org/0000-0003-2819-5703 \\ ${ }^{6}$ Department of Tourism and socio-humanitarian disciplines, Kharkiv College of Trade and Economics of Kyiv National University of \\ Trade and Economics, Kharkiv, Ukraine \\ ORCID: http://orcid.org/0000-0002-6116-264X
}

Article history:

Received date 12.05 .2020

Accepted date 18.06.2020

Published date 30.06.2020

\section{Section:}

Communication Studies

D O

$10.21303 / 2313-8416.2020 .001347$

KEYW OR D S

\section{globalization}

intercultural communication

transcultural communication

education

gender

global learning

multiculturalism

information society

knowledge society

risks
This study, the object of which is globalization in its modern modifications, is devoted to the analysis of trends in the deployment of globalization processes in modern sociocultural contexts. The features of postmodern societies, which are informational and multicultural societies, risk and knowledge societies are analyzed. Based on the author's comprehensive research methodology, globalization, its structure, semantics, functional range and constructive potential are considered. Particular attention is paid to intercultural communication as a tool to overcome possible "zones of misunderstanding." It turns out its horizontal and vertical dimensions, gender communication is considered as an example of horizontal deployment. The role of education and upbringing in the formation of the imperative of tolerance is highlighted. It is proved in the work that taking into account the unity of these measurements is of fundamental importance for increasing the efficiency of the formation of a person's readiness to respond to life's challenges.

Investigated problem. Among modern challenges, globalization pays special attention, absorbs light at an accelerated pace. Despite the fact that this thematic field was developed by a number of researchers, this problem remains relevant today especially since sociocultural contexts are changing, emphasis is shifting. Due to the global pandemic, the corona of the virus of the state is becoming more closed. The perception of globalization processes occurs through an analysis of potential risks for self-preservation. Despite this, integration processes continue, therefore, teaching a person intercultural communication skills remains relevant.

The main scientific results. The scientific novelty of research is to create a metatheoretical model of globalization and intercultural communication as its component in general civilization and national contexts on the basis of the author's methodological program, the application of which made it possible to significantly deepen the understanding of the globalization construct, to reveal the functional potential of intercultural communication as necessary in the construction and implementation of successful life-saving strategies. Scope of the practical application of the research results. Practical value is determined by the totality of the analyzed problems, which expand the horizons of understanding the phenomenon of globalization and intercultural communication. The proposed methodological research program can be used in the further development of problems of national education strategies in the era of globalization, in the teaching of special courses in the philosophy of education, theoretical and comparative pedagogy, the sociology of education and culture. The results of the study were introduced into the educational process of the H. Skovoroda Kharkiv National Pedagogical University, the Ternopil V. Hnatiuk National Pedagogical University, the Kharkiv College of Trade and Economics of the Kyiv National University of Trade and Economics. 


\section{Introduction}

The radical changes that modern societies are going through now require a certain revision of the already familiar approach to understanding globalization, a deeper analysis of its potential risks. Unfortunately, the coronavirus pandemic, the consequences of which, perhaps, provoke the activity of antiglobalistic movements, which lost their positions at the end of the last century, has also confirmed this. Societies must be prepared for potential challenges. So, a deep analysis of the identified problem should lead to a mitigation of the process of overcoming them.

\section{1. The object of research}

The object of this research is globalization in its modern modifications.

\section{2. Problem description}

1. 2. 1. Justification of the functional potential of the study of the features of modern social challenges

Despite the fact that the degree of development of the problem that is analyzed is quite high, new circumstances give rise to promising lines of research. In particular, the study of the significant role of education in modern sociocultural contexts requires special attention.

Education is one of the priority sectors of the state's life, has a huge impact on the formation of public opinion on various issues, is forced to respond to the challenges of globalization, adapt its answers to them in the conditions in which its civilization mission and humanistic purpose are realized.

Another challenge of our time is the excess of all kinds of innovations, including the need to absolutize distance learning through quarantine requirements, and, accordingly, the intensification of contacts with Alien and others arising from the use of information technology [1]. The inability to communicate in a physically real plane and replacing it with a virtual one can complicate the overcoming of the so-called "lacunae" (from Latin Lacuna --moat, that is, zones of misunderstanding). Lacunae can change, combine with each other, structuring certain hierarchies of lacunae. Thus, the lacunae model is a dynamic methodological model that allows to overcome the frozen, antihistorical understanding of culture, and then allow to quickly identify the complexity of intercultural communication.

In such complicated socio-cultural contexts, intercultural communication, which takes place in certain horizontals and verticals, is of paramount importance. An example of the latter can be communication between representatives of different generations. As for horizontal deployment, as an example it is possible to talk about gender communication.

So, the issue of preserving a global society, the outlines of which have become more clear in recent years, and now are in jeopardy, require the construction of a new educational profile, in particular, where training and the formation of intercultural communication skills arise as an important tool [2].

\section{2. 2. Prerequisites for the multiplicity of manifestations of intercultural commu-} nication

The study of intercultural communication presupposes, first of all, differences in its reality and reflection. This is complicated by the fact that intercultural communication simultaneously acts as the subject and method of research. It not only produces a message about other cultures, but also teaches how to make such messages from the flows of information about other cultures, how to understand and structure it, and integrate it into your life experience. So, in order to make this communication a component of social learning in the broadest sense, as understood by Y. Habermas, that is, as the assimilation of specific or inherited patterns of behavior [3], it is necessary to distinguish between the level of reality and the level of theoretical reflection.

The reality of intercultural communication is represented by numerous speech acts in which messages are exchanged about other cultures in their various representations. At this level, it is characterized by an excess of cultural meanings, options, offers. So, it is the cultural polyphony of human civilization, in which it is necessary to learn to distinguish and understand not only the self-representations of different cultures, but also actively act, master new complicated sociocultural situations, and constitute transcultural spaces with monads of national cultures. 
As already noted above, speaking about reality, it should be noted once again that in modern conditions intercultural communication can unfold and unfold not only horizontally, that is, as communication with various existing or sub-cultural cultures and subcultures, but also vertically - with different cultures of knowledge and cultural techniques, political and legal cultures, everyday cultures that were once, but still have a powerful communicative memory. To comprehend such a complex phenomenon as cultural communication, it is necessary to carry out a comprehensive study of both dimensions. Let's consider, for example, the problem of gender communication, which unfolds horizontally.

\section{2. 3. Gender communication as a kind of intercultural intersection}

In the understanding of the representatives of the socio-constructivist approach, gender is constituted by culture and created in social interaction; in each situation, an individual models gender differently $[4,5]$. Therefore, it is possible to talk about the present variability of gender identities of communication subjects. That is, much more heterogeneity than traditional binary oppositions: male-female.

Lack of awareness of gender issues often leads to the following situation: a subject who does not fit into stereotypically existing norms will be excluded from communication because it is considered Other and Alien.

An important role in promoting gender issues should be played by the institution of education. After all, education is an environment of socialization that constantly reproduces irregularities. The formation of a person's personality begins in childhood, where educational institutions play an important role as socialization agents. This issue was reflected in the research of experts Gender information and analytical center "KRONA". In particular, it was noted that the school is a place for the development of gender inequality, in order to increase gender competence and develop gender sensitivity, teachers were offered strategies to overcome sexism in school [6]. It is not possible to separate the kindergarten from the school, because together they demonstrate the continuity and interconnection of behavioral patterns and stereotypes that are formed and interfere with the free personal realization of children. Attention is focused on the need to implement comprehensive gender education "from birth to school graduation", in which both teachers, the administration of institutions, and parents would participate, which would create the conditions for the comprehensive development of children, casting doubt on the traditional gender dichotomy [7]. Based on previous studies and experts' own experience, an experimental project was implemented to turn the modern Ukrainian school into a gender-sensitive institution, in which 8 educational institutions of the Kharkiv region took part [8]. Since the process of introducing gender policy into the educational sector has resonated over the past decades, the cycle "kindergarten-school-institution of higher education" is impossible for modern students, therefore, HEIs are also responsible for education in this matter. It is not enough just to have appropriate gender centers at educational institutions; it is necessary to constantly conduct seminars, trainings, create training courses and generally engage in educational activities [9]. Particular attention should be paid to the language, since it is a variable construct and reflects reality. It demonstrates and captures in itself social inequality, which can be corrected with the help of speech strategies: feminization and neutralization. All of the above is necessary to eradicate gender stereotypes and contribute to the establishment of a democratic society.

Also, since global pandemics have an impact on gender equality, in the context of the latter, the gender issue is important, because this may be the first case of registering gender and gender differences and taking them into account in the future by researchers and policy makers.

\section{2. 4. The concept of subculture in postmodern ontologies.}

So, based on section 1.2.3 of this research, it is possible to see that in a sense, gender communication is presented as communication between representatives of subcultures.

For a holistic analysis of the phenomenon of intercultural communication, it is important to clarify the cognitive capabilities of the concept of subculture. In a broad sense, subculture is the culture of a group of people united by specific interests that determine their worldview. Subculture is a sovereign holistic entity, part of social culture. A subculture may differ from a dominant culture in language, demeanor, clothing, etc. Some subcultures are extreme in nature and demonstrate 
protest against society or its individual phenomena. Some subcultures are closed and isolated from society. Sometimes subcultures develop and enter as elements in a dominant culture [10].

\section{2. 5. Dialogue as a guarantee of overcoming "zones of misunderstanding"}

Speaking about the practical level of intercultural communication, it should be emphasized that it always takes the form of dialogue. Today, dialogue is becoming an imperative for partnering. According to the principles of dialogue, the constitution of pedagogical, family and even industrial relations is required. Openness to dialogue in modern societies is perceived as a sign of civilization [11]. Strengthening the social significance of the dialogue requires a more detailed consideration of the prerequisites for its successful implementation.

Communication in the form of a dialogue is realized as a life principle, as an exchange of opinions in written or verbal questions and answers, or speeches and counter-promises of two or more persons [12].

Returning to the special living conditions in an emergency caused by the global pandemic, it provides for rather strict restrictions, so there is not enough opportunity to conduct a dialogue in a real physically defined plane (face to face), and not virtually. Despite the high level of development of information technologies, they can't always convey the whole spectrum of human feelings, the peculiarity of the atmosphere prevailing, the absence of an audience of listeners nearby makes it difficult to track certain reactions.

Dialogue presupposes openness, its purpose is to clarify the meanings, determine the prospects for interaction and, ultimately, the development of personalities of the participants in the dialogue. Dialogue differs from a dispute or other forms of heuristic in that there are no winners and losers in it, but positions are explicated. Dialogue is inherent in internal tension, interest in the subject and in the interlocutor. In the communicative space of dialogue, the interests of the interlocutors intersect and reality is constructed. In the case of intercultural communication, a bicultural or multicultural reality is constructed through dialogue, and unique portals are created for entering a different culture.

So, intercultural dialogue is a form of communication between different cultures [13]. This communication is carried out at the formal and informal levels. The educational dimension is one of the determining factors in this dialogue, because understanding an alien culture requires the development of appropriate skills among the participants in the dialogue. Intercultural dialogue is multidimensional and complex structured, an important prerequisite for its implementation is the knowledge of cultural standards, the carrier of which is the interlocutor. These standards set strategies for intercultural dialogue, allow to set untouched limits of identity, the violation of which leads to the cessation of dialogue. Intercultural educational dialogue is philosophical and pedagogical, it produces self-observation and self-description.

A prerequisite for a successful dialogue is the existence of anthropologically sound cultural standards. In modern cultural anthropology, such standards are understood to mean "all types of perception, thinking, evaluation and actions that are taken for granted, normal, recognized and typical of most representatives of a certain culture. Own and alien behavior is evaluated and regulated on the basis of cultural standards" [14].

Thus, intercultural dialogue is a universal cultural form of intercultural communication.

So, intercultural communication is a complex and multidimensional phenomenon. The study of its manifestations and the formation of intercultural skills is extremely necessary in modern societies, most of which are multicultural. Man and society must be prepared for the challenges of globalization and the possible return of anti-globalization rhetoric. Today it is possible to hear forecasts that the world will become more closed. But the formation of the world community has already taken place and has fully justified itself. Euro-integration processes should continue, because most countries, and Ukraine among them, have clearly decided on the course of unification. On certain thoughts that globalization carries the risk of losing national identity, and that the global language ("global English") is a threat to other national languages, it should be noted that most countries have come to unity and have preserved their national cultural heritage [15]

\section{3. Proposed solutions of the problem}

The problem of globalization in planetary and local dimensions has been considered by many researchers - philosophers, sociologists, political scientists, educators representing various 
currents and directions and, accordingly, are repelled from different initial positions. So, for example, from the standpoint of modern communicative philosophy and the ideas of dialogical and critical pedagogy, K.-O. Apel [16, 17], G. Batishchev [18], M. Bakhtin [19, 20], A. Bolnov [21], M. Buber [22], E. Birkenbeil [23], J. Habermas [3], N. Luman [24, 25] and others.

Considering that a certain focus of our study is the analysis of the functional potential of intercultural dialogue, let's single out the work of V. Andrushchenko [26, 27], M. Kultaeva [28, 29] and others.

The deep understanding of the anthropological status of intercultural communication, as well as the conceptualization of our and Alien's problems, are overviewed in the works of B. Waldenfels [30, 31], V. Malakhov [32, 33] and others.

On the development of the problems of a multicultural society and multiculturalism, the ideas of R. Sennett [34, 35], C. Taylor [36, 37] and others turned out to be fruitful.

Despite the existence of a wide range of research topics, this problem has been further investigated through its dialectical character, which changes under the weight of the influence of modern sociocultural contexts, which are constantly updated.

Timely analysis of contemporary sociocultural contexts containing certain challenges will provide mitigation of their overcoming when a person is ready for it. The concept of forming a person's readiness to meet the challenges of our time should be introduced into educational and upbringing practices through a straight line. One of these is globalization, which puts pressure on people. The development of intercultural communication skills will help a person to respond to this challenge without stress. For this purpose, an author's analysis of the phenomenon of globalization and intercultural communication as integral attributes of modernity has been developed.

So, the aim of research is to determine the risks of globalization pressures on a person in modern sociocultural contexts and develop recommendations to mitigate their overcoming on the basis of philosophical, anthropological and systematic theoretical analysis.

\section{Materials and methods}

The study was carried out on the basis of a comprehensive methodology, which is built on the basis of a complementary combination of phenomenological, hermeneutic, contextually, structurally-functional and system-theoretical analysis, as well as the historical-genetic method and the method of anthropological interpretation. The interdisciplinary approach and methodological foundations of comparative studies became cross-cutting in the study, the appropriateness of the application of which is due to the very nature of globalization and intercultural communication in its empirical givenness and theoretical task, summarized through the method of climbing from abstract to concrete the results of cultural, historical, sociological and psychological-pedagogical studies in this plane.

\section{Results}

On a complementary basis, a structural-functional and existential-anthropological analysis of the phenomenon of globalization is carried out. The necessity of updating the perception of this phenomenon, overcoming the theoretical and methodological patterns and stereotypes prevailing in the pre-modern day is taken into account. As a result of the analysis, a metatheoretical program is developed to prepare a person for confrontation with globalization challenges; it has gained introduction through institutionalization of appropriate special courses for children, students and ordinary citizens of different ages. It is proved that taking into account the unity of all dimensions is of fundamental importance for increasing the efficiency of preparing a person to overcome globalization pressure. The heuristic potential of the approach to subcultural communication is substantiated and revealed. Subcultural communication as a universal cultural form is the realization of the transcendental essence of man. Subcultural dialogue, which is a synthesis of dialogical forms, preserves the heuristic functionality of the dialogue. At the macro level, subcultural communication is turning into a polylogue in the plane of factual and counterfactual on the example of gender communication, the dialectical unity of globalization, intercultural and subcultural communication is revealed. Their synthesized meanings are highlighted. They are in the risks of a collision of their own and the Alien, or the Other. The general cultural conditions for the establishment of tolerance and humanism in the worldview culture of modern man are determined. The importance 
of preparing a person for life under the pressure of globalization to overcome the consequences of social and cultural injuries per day of radical social and cultural changes is disclosed.

\section{Discussion}

Despite the social and civilizational-cultural significance of the phenomenon of globalization and such answers to its challenges as intercultural and subcultural communication, certain gaps remain in this thematic field. In our study, let's rely on the theoretical principles of modern communicative philosophy, sociology, as well as on the ideas of dialogical and critical pedagogy. Especially here it should be noted the work of K.-O. Apel, G. Batishchev, M. Bakhtin, A. Bolnov, M. Buber, J. Habermas, V. Hosle, A. Ermolenko, N. Luman, L. Sitnichenko, P. Freire and others. Of fundamental importance for the study of globalization the discourse of cultural and educational globalization, a significant contribution to which in the thematic plane of this study was made by V. Andrushchenko, V. Beck, A. Giddens, M. Kultaeva, M. Mikhalchenko, V. Skotny, N. Scotna, and others. In approach to understanding global processes, achievements and the risks associated with them, let's took into account the achievements of predecessors. In the framework of the proposed study, it is impossible to exhaustively reveal the phenomenon of globalization through its versatility and complexity. We did not set the goal, in particular, of analyzing such challenges of globalization as the problems of coexistence of representatives of various religious faiths in modern sociocultural contexts or the issue of perceiving the views of representatives of sexual minorities. Therefore, the formation of a culture of tolerance in this aspect can become a promising line of research.

\section{Conclusions}

Globalization is a complex structured process of approximation of cultures and cultural meanings, which are not only subjective experiences, but also cultural objectivization. The metatheoretical model of globalization allows to combine the macro and micro perspectives of the experience of meeting different cultures and subcultures. This suggests a pluralistic representation of globalization. Its empirical factuality and counterfactual implication, existing in the general horizon, can create communicative paradoxes. Intercultural communication acts as a mechanism that includes a powerful potential, teaches the communicative techniques of dialogue between cultures. Today's modifications of globalization are caused, in particular, by the tragic consequences of the global pandemic coronavirus. States are becoming more closed, increasingly considering the possible mobility risks of the globalization element. However, in the vast majority, modern intercultural dialogue is characterized by a humanistically directed selection of its meanings on the basis of a universal macroetics of responsibility. Its representations at the official and unofficial levels do not match. Taking this point into account is important in the practical organization of educational and upbringing practices aimed at developing a tolerant attitude towards others.

\section{References}

[1] Huntington, S. P. (1993). The Clash of Civilizations? Foreign Affairs, 72 (3), 22-49. doi: http://doi.org/10.2307/20045621

[2] Burbules, N. C.; Neiman, A. (Ed.) (1996). Postmodern Doubt and Philosophy of Education. Philosophy of Education 1995. Urbana: Philosophy of Educational Society, 39-48.

[3] Habermas, J. (1981). Theorie des kommunikativen Handelns. Bd. 2. Frankfurt am Main. Suhrkamp.

[4] Uest, K., Zimmerman, D.; Zdravomyslovoi, E., Temkinoi, A. (2000). Sozdanie gendera. Khrestomatiia feministskikh tekstov. Saint Petersburg: Izdatelstvo «Dmitrii Bulanin», 193-219.

[5] Batler, Dzh. (2000). Gendernoe bespokoistvo. Gl. 1. Subekty pola/ gendera/ zhelaniia. Antologiia gendernoi teorii. Minsk: Propilei, 297-346.

[6] Marushchenko, O., Plakhotnik, O. (2012). Henderni shkilni istorii. Kharkiv: Monohraf, 88.

[7] Andrusik, O., Vodolazhskaia, N., Efimceva, A. et. al.; Andrusik, O., Maruschenko, O. (Eds.) (2013). V poiskakh gendernogo vospitaniia. Kharkiv: Zolotye stranicy, 144.

[8] Andrusyk, O., Marushchenko, O., Masalitina, O. (Eds.) (2018). Hender yide. Kharkiv: Planeta - Prynt, 128.

[9] Skinder, N. V., Torianik, I. P. (2020). Ways of Promoting Gender Education. Osvita i nauka u minlyvomu sviti: problemy ta perspektyvy rozvytku. Dnipro: SPD «Okhotnik», 1, 273-274.

[10] Orestad College. Available at: http: //cikavo.com/article/7853.html

[11] Burbules, N. C. (1993). Dialogue in Teaching: Theory and Practice. New York: Teachers College Press. Columbia University, 23-76. 
[12] Meyers Enzyklopädisches Lexikon (1980). Bd. 6. Berlin: Akad.-Verlag.

[13] Tryniak, M. V. (2011). Interkulturna komunikatsiia v osviti: tendentsiia rozghortannia u suchasnykh sotsiokulturnykh kontekstakh. Kharkiv.

[14] Thomas, A.; Thomas, A. (Ed.) (1993). Psychologie des interkulturelles Lernens und Handelns. Kulturvergleichende Psychologie. Eine Einführung. Göttingen-Toronto: Klett, 377-424

[15] Selby, D. (2000). Global Education as Transformative Education. Zeitschrift fur internationale Bildungsforschung und Entwicklungspadagogik, 23 (3), 2-10.

[16] Apel, K.-O. (1996). Obgruntuvannia etyky vidpovidalnosti. Pershodzherela komunikatyvnoi filosofii. Kyiv. Lybid, 46-59.

[17] Apel, K.-O. (1998). Auseinandersetzungen in Erprobung des transzedentalpragmatischen Ansatzes. Frankfurt am Main: Suhrkamp.

[18] Batyshchev, H. S. (1997). Dyalektyka obshchenyia. Moscow: Nauka.

[19] Bakhtin, M. M. (2000). Avtor i geroi: K filosofskim osnovam gumanitarnykh nauk. Saint Petersburg: Azbuka, 336.

[20] Bakhtin, M. M. (1986). K filosofii postupka. Filosofiia i sociologiia nauki i tekhniki. Ezhegodnik, 1984-1985. Moscow: Nauka, 80-159.

[21] Bolnov, O. F., Sytnychenko, L. A. (1996). Zustrich. Pershodzherela komunikatyvnoi filosofii. Kyiv: Lybid, 157-170.

[22] Buber, M. (1995). Ia i ty. Moscow: Respublika.

[23] Birkenbeil, E. J. (1984). Erziehungsphilosophie des Dialogischen. Frankfurt am Main: Verlag Peter Lang.

[24] Luhmann, N. (1996). Einführung in die Systemtheorie. Heidelberg: Kohlhammer.

[25] Luhmann, N. (1986). Ökologische Kommunikation. Opladen: Leske\&Budrich. doi: http://doi.org/10.1007/978-3-322-94325-5

[26] Andrushchenko, V. P. (2004). Rozdumy pro osvitu: Statti, narysy, interviu. Kyiv: Znannia Ukrainy, 804.

[27] Andrushchenko, V. P. (2006). Filosofiia osvity KhKhI stolittia: u poshukakh perspektyvy. Filosofiia osvity, 1 (3), 6-12.

[28] Kultaieva, M. D., Navrotskyi, O. I., Sheremet, I. I. (2008). Yevropeiska teoretychna sotsiolohiia XX-XXI stolittia. Kharkiv: KhNU imeni V. N. Karazina, 332.

[29] Kultaieva, M., Prokopenko, I. F., Radionova, I. O., Trotsko, H. V. (2008). Sotsiolohiia hlobalizatsii. Kharkiv: KhNPU imeni H. S. Skovorody.

[30] Valdenfels, B. (2009). Mirkuvannia shchodo henealohii kultury. Filosofska dumka, 1, 13-26.

[31] Valdenfels, B. (2004). Topohrafiia Chuzhoho: studii z fenomenolohii Chuzhoho. Kyiv: PPS, 206.

[32] Malakhov, V. (1991). Natsiia v poli kulturi. Filosofska i sotsiolohichna dumka, 8, 94-98.

[33] Abolina, T. H., Yermolenko, A. M., Kyselova, O. O., Malakhov, V. A. (1997). Problema obgruntuvannia etychnykh norm i tsinnostei v konteksti kultury: transformatsiia i mezhi ontolohichnoho pidkhodu. Etychni normy i tsinnosti: problemy obgruntuvannia. Kyiv: Stylos, 6-66.

[34] Sennett, R. (1998). The Corrosion of Character. New York.

[35] Sennett, R. (1970). The Uses of Disorder. New York, London: Un. Press.

[36] Teilor, Ch. (2002). Etyka avtentychnosti. Kyiv: Dukh i litera, 128.

[37] Teilor, Ch. (2004). Multykulturalizm i „Polityka vyznannia”. Kyiv: Alterpres. 